\title{
(In,Mn)As квантовые точки: синтез и оптические свойства
}

\author{
А.Д. Буравлев \\ Санкт-Петербургский Академический Университет РАН \\ Физико-Технический Институт им. А.Ф Иоффе РАН \\ Санкт-Петербургский Электротехнический Университет \\ Институт Аналитического Приборостроения РАН \\ *E-mail: bour@mail.ioffe.ru
}

DOI:10.31868/RFL2018.25

На сегодняшний день наноструктуры на основе ферромагнитных полупроводников (или, так называемых, разбавленных магнитных полупроводников (РМП)) рассматриваются в качестве перспективных объектов для управления спиновыми взаимодействиями посредством как электрических, так и оптических методов и, соответственно, для создания новых устройств спинтроники, в том числе, таких как, например, спиновые светоизлучающие диоды и лазеры [1-3]. При этом, локальное распределение спинов в таких наноструктурах, по-видимому, зависит не только от их размеров, но и от их формы. Это вызывает много вопросов относительно образования таких наноструктур, в том числе квантовых точек.

Известно, что обычно тонкие пленки РМП соединений синтезируют при относительно низких ростовых температурах для того, чтобы избежать образования вторичных фаз. В свою очередь, нами были разработали новые методы для синтеза с помощью молекулярно-пучковой эпитаксии (МПЭ) (In,Mn) As квантовых точек [4,5] и нитевидных нанокристаллов [6] при относительно высоких температурах роста. При этом, МПЭ синтез (In,Mn)As квантовых точек основывался на селективном легировании Мn центральных частей квантовых точек. Изучение структурных свойств полученных образцов показало, что несмотря на относительно высокую температуру роста, образцы с (In,Mn)As квантовыми точками обладают высоким кристаллическим качеством. Стоит отметить, что с использованием данного технологического подхода также были синтезированы структуры с многослойными квантовыми точками.

На основе (In,Mn)As квантовых точек, использовавшихся в качестве активных слоев, были созданы p-i-n диоды, оптоэлектронные свойства которых были исследованы как при оптической, так и электрической накачке.

\author{
Литература \\ [1] R. Fiederling et al., Nature 402, 787 (1999). \\ [2] Y. Ohno et al., Nature 402, 790 (1999). \\ [3] N. Nishizawa et al., Proc. Natl. Acad. Sci. U.S.A. 114, 1783 (2017). \\ [4] A. Bouravleuv et al., Semiconductors 47, 1037-1040 (2013). \\ [5] A. Bouravleuv et al., Appl. Phys. Lett. 105, 232101 (2014). \\ [6] A. Bouravleuv et al., Nanotechnology 27, 425706 (2016).
}

